\title{
The Attitudes of Students from ESL and EFL Countries to English
}

\author{
Muhamad Hasbi \\ English and Foreign Languages University \\ Hyderabad - 500 007, Andhra Pradesh, India \\ hasbi.muhamad@yahoo.com
}

\begin{abstract}
This research is to study the attitudes of English students from English as a Second Language (ESL) and English as a Foreign Language (EFL) country in English and Foreign Languages University (EFL University), Hyderabad to English. This is a descriptive-quantitative research with a survey method. The attitudes researched include those to listening, speaking, reading, and writing. The data was taken through questionnaire consisting of 20 questions. The findings of this study showed that the English students in EFL University have neutral-to-positive attitudes to Listening, positive attitudes to Speaking, positive attitudes to Reading, and poor attitudes to Writing. In addition, the English students from ESL country have better attitudes to Reading (positive) and Writing (neutral) and those from EFL country have better attitudes to Speaking (neutral-topositive) and Listening (neutral-to-positive).
\end{abstract}

Keywords: Attitudes, English as a Second Language (ESL), English as a Foreign Language (EFL)

\section{Abstrak}

Penelitian ini bertujuan untuk meneliti sikap mahasiswa jurusan bahasa Inggris yang berasal dari Negara yang menggunakan bahasa Inggris 
sebagai bahasa kedua (EFL) dan yang menggunakan bahasa Inggris sebagai bahasa asing (EFL) di Universitas Bahasa Inggris dan Bahasa Asing (English and Foreign Languages University/EFL University), Hyderabad terhadap bahasa Inggris. Penelitian ini adalah penelitian deskriptif-kuantitatif dengan menggunakan metode survey. Sikap yang diteliti termasuk sikap terhadap mendengarkan, berbicara, membaca, dan menulis. Data diperoleh melalui kuesioner yang terdiri dari 20 pertanyaan. Hasil penelitian ini menunjukkan bahwa mahasiswa di EFL University memiliki sikap netral ke positif terhadap mendengarkan, sikap positif terhadap berbicara, sikap positif terhadap membaca, dan sikap yang kurang positif terhadap menulis. Mahasiswa dari negara ESL memiliki sikap yang lebih baik terhadap membaca (positif) dan menulis(netral) dan mereka yang berasal dari negara EFL memiliki sikap yang lebih baik terhadap berbicara (netral ke positif) dan mendengarkan (netral ke positif)

Keywords: Sikap, Bahasa Inggris sebagai Bahasa Kedua, Bahasa Inggris sebagai Bahasa Asing

\section{Introduction}

Day to day, English becomes so familiar for people around the world due to its role as a lingua franca and an international language used in almost fields of life. International relationship, mass communication, business, education, politics, and others are established primarily using English. This condition then triggers people around the world to learn English, either for academic or specific purposes.

Because of the reasons, English study has become a branch of science with limitless knowledge discussed by linguists and learners. English books have continuously been on the first rank publication of language books for years back and predictably for years after. Therefore, the development of methods and approaches to the teaching and the 
learning of English becomes one of the major expert attentions so as to make the English learning more successful and effective.

The teaching and the learning of English can never be aside from the four language skills (reading, writing, listening, speaking) and two language components (grammar and vocabulary). Teachers will have to have a lot of efforts in designing and developing their teaching methods and approaches to help students learn better. In addition, the learners will have to have several efforts in doing classroom as well as independent learning which are initially influenced by their own attitudes towards English.

The attitudes towards English are considered as a very basic as well as crucial to the successfulness of students' learning. It is believed that the attitudes consisting of the way the learners think, feel, and behave towards English, count for learners' intention, process, and so result of English learning. Considering the importance of this phenomenon, the writer intends to investigate how far the attitudes of English contribute to the successfulness of their learning. Furthermore, the writer also compares the attitudes of learners from EFL and ESL countries since there are some universal differences in terms of their accessibility, environmental and educational supports towards English learning.

In this study, the writer would like to figure out these following questions: (1) how far are the attitudes of English students in EFL University to English? (2) how far are the attitudes of English students from ESL country compared to those from EFL country? (3) how far are 
the attitudes of students from EFL country compared to those from ESL country?

\section{Attitudes}

'Attitude' is defined as the way in which a person thinks (cognitive component), feels (affective component), and intends to behave(behavioural component) towards something (Rajecki, 1982:33). It underlines the summation of the three components united as a package of competence of a person who determines the successfulness of one's addressed effort. Further, Wenden (1991) explains that the cognitive component is made up of the beliefs andideas or opinions about the object of the attitudes; the affective one refers to the feelings and emotions that one has towards an object, 'likes' or 'dislikes', 'with' or 'against'; and finally, the behavioural component refers to one's consisting actions or behavioural intentionstowards the object.

Learning a language is closely related to the attitudes towards the languages (Starks \&Paltridge, 1996). English language learning, similarly, is also an effort done by a learner towards the mastery of English for his or her intended purpose. In reference to Rajecki's definition, English learning attitudes will include learners' thinking, feeling, and behavior sprung during his English learning. Smit (1996) adds that language attitudes can be defined as strong positive or negative emotionsexperienced by people when they are faced with a choice between languages in a variety of situations or a variety of language learning.

One's attitude towards English either positive or negative, will then strongly influence his intention, orientation, effort, and result of his 
learning. Karahan (2007) avers that "positive language attitudes let learner have positive orientation towards learning English"; inferring that negative language attitude, in vice versa, will bear negative orientation.

In a further extension, this attitude can be broken down up to the branches of English skills, i.e., listening, speaking, reading, and writing. This means that a learner can actually has a various type of attitudes in each of the skills. This is because one's thought, feeling, and behavior towards a particular skill may be different, slightly or strongly, from the other skills. Thus, it can be found that a learner probably has a good attitude in reading and or writing but poor in speaking and or listening. At last, this phenomenon stimulates the writer's willingness to research deeper on learners' attitude to those four various skills, rather than generally to only English language.

\section{English as a second language (ESL)}

English as a second language (ESL) belongs to those whose English is a secondary language used for a particular purpose and in a particular situation. This English has a meaningful significance, yet, is not used as primary spoken language in daily communication. The users have their own language, either mother tongue or national language, used in everyday speaking. India, for instance, has ESL.

\section{English as a foreign language (EFL)}

English as a Foreign Language (EFL) belongs to those whose English is a foreign language used for a limit purpose and in a limit situation. This English has an occasional significance, so is used in a 
particular occasion, such as in English classroom, international symposium, etc. The users have their own language to use in everyday speaking. Countries such as Indonesia, Bhutan, Iran, Iraq, etc have their English as EFL.

\section{Research method}

Based upon the research procedures which had been conducted later on, this study is included into quantitative research (Sugiyono, 2008:v). In terms of the natural setting, this is included in a survey research (Sugiyono, 2008: 4). Survey research is used to find out facts from research setting naturally and the researcher uses treatments for collecting the research data. The treatments can be in the form of questionnaires, tests, structural interviews, and the like (Sugiyono, 2008: 6). As Cohen, at.al. (2000) says,

Typically, surveys gather data at a particular point in time with the intention of describing the nature of existing conditions, or identifying standards against which existing conditions can be compared, or determining the relationships that exist between specific events. Thus, surveys may vary in their levels of complexity from those which provide simple frequency counts to those which present relational analysis.

The object of this research is the attitudes of English students from ESL country and those from EFL country studying MA English program in EFL University, Hyderabad. The attitudes researched include those to listening, speaking, reading, and writing. The data was taken through questionnaire consisting of 20 questions of which every 5 questions belonged to one particular category of the four English skills. The questionnaire used five optional answer types, i.e., always, often, 
sometimes, seldom, and never. There were 20 respondents; 10 of them were students from ESL country, here India, and the other 10s were from EFL country randomly chosen from Afghanistan, Bhutan, Indonesia, Iran, Iraq, Oman, and Tajikistan.

The data was then analyzed descriptively. The answer frequency of occurrence of the highest percentage determined to what attitude the students belonged. The category of the attitude along with its mean percentage range of answers follows this criterion:

- $\left.\begin{array}{l}\text { always } \\ \text { often }\end{array}\right\}$ 'positive attitude'

- sometimes $\rightarrow$ 'neutral attitude'

- seldom

- never

\} 'negative attitude'

Thus, later in the discussion, a positive attitude is given if the total sum of 'always' and 'often' answers is majority than the others; a neutral attitude is given if the total sum of 'sometimes' answer is majority; and, a negative attitude is given if the total sum of 'seldom' and 'never' answers is majority compared to the others.

\section{Discussion}

The questionnaires filled by the 20 respondents, and they were united to be recapitulated as a final data. Below are the final data together with their analysis presented in four parts based on each language skill.

\section{Students' attitude towards listening (question 1-5)}

To investigate students' attitude to listening, the writer performed these 5 questions to be filled.These five questions were given to detect students' attitude in listening skill specifically on five elements indicating 
the attitude, including their habit $(\mathrm{Q} 1)$, readiness $(\mathrm{Q} 2)$, accessibility $(\mathrm{Q} 3)$, comprehension (Q4), and evaluation (Q5) toward English listening.

Table 1

Questionnaire Data Preview on Listening Skill

\begin{tabular}{|c|c|c|c|c|c|c|c|c|c|c|c|}
\hline No. & Statements & \multicolumn{2}{|c|}{ always } & \multicolumn{2}{|l|}{ often } & \multicolumn{2}{|c|}{ sometimes } & \multicolumn{2}{|c|}{ seldom } & \multicolumn{2}{|c|}{ never } \\
\hline \multirow[t]{2}{*}{1.} & $\begin{array}{l}\text { I used to listen to either English } \\
\text { conversation, songs, or movies to } \\
\text { improvemy English }\end{array}$ & $15 \%$ & $3 \mathrm{~F}$ & $45 \%$ & $\begin{array}{l}4 \mathrm{~S}, \\
5 \mathrm{~F}\end{array}$ & $35 \%$ & $\begin{array}{l}65, \\
1 F\end{array}$ & $5 \%$ & IF & & \\
\hline & Percentage of attitude value: & \multicolumn{4}{|c|}{$60 \%$} & \multicolumn{2}{|c|}{$35 \%$} & \multicolumn{4}{|c|}{$5 \%$} \\
\hline \multirow[t]{2}{*}{2.} & $\begin{array}{l}\text { Ido not need English subtitle text } \\
\text { anymore while watching English } \\
\text { movies }\end{array}$ & & & $10 \%$ & $2 \mathrm{~F}$ & $65 \%$ & $\begin{array}{l}65 \\
7 \mathrm{~F}\end{array}$ & $15 \%$ & $3 \mathrm{~S}$ & $10 \%$ & $\begin{array}{l}15, \\
1 F\end{array}$ \\
\hline & Percentage of attitude value: & \multicolumn{4}{|c|}{$10 \%$} & \multicolumn{2}{|c|}{$65 \%$} & \multicolumn{4}{|c|}{$25 \%$} \\
\hline \multirow[t]{2}{*}{3.} & $\begin{array}{l}\text { Since childhood, Iget easy access to } \\
\text { listen to English language (from } \\
T V, \text { songs \& movies, society, etc) }\end{array}$ & $10 \%$ & $2 S$ & $20 \%$ & $\begin{array}{l}2 S, \\
2 \mathrm{~F}\end{array}$ & $35 \%$ & $\begin{array}{l}2 S, \\
5 F\end{array}$ & $25 \%$ & $\begin{array}{l}35, \\
2 \mathrm{~F}\end{array}$ & $10 \%$ & $\begin{array}{l}15, \\
1 F\end{array}$ \\
\hline & Percentage of attitude value: & \multicolumn{4}{|c|}{$30 \%$} & \multicolumn{2}{|c|}{$35 \%$} & \multicolumn{4}{|c|}{$35 \%$} \\
\hline \multirow[t]{2}{*}{4.} & $\begin{array}{l}\text { I can understand the varieties of } \\
\text { spoken English of foreigners I ever } \\
\text { met and talked to }\end{array}$ & $15 \%$ & $\begin{array}{l}1 S, \\
2 \mathrm{~F}\end{array}$ & $25 \%$ & $\begin{array}{l}4 \mathrm{4S}, \\
\mathrm{lF}\end{array}$ & $40 \%$ & $\begin{array}{l}2 S \\
6 \mathrm{~F}\end{array}$ & $20 \%$ & $\begin{array}{l}3 S, \\
1 F\end{array}$ & & \\
\hline & Percentage of attitude value: & \multicolumn{4}{|c|}{$35 \%$} & \multicolumn{2}{|c|}{$40 \%$} & \multicolumn{4}{|c|}{$35 \%$} \\
\hline \multirow[t]{2}{*}{5.} & $\begin{array}{l}\text { Iused to get good markin English } \\
\text { listening activity }\end{array}$ & $20 \%$ & $\begin{array}{l}15, \\
3 \mathrm{~F}\end{array}$ & $45 \%$ & $\begin{array}{l}5 \mathrm{~S}, \\
4 \mathrm{~F}\end{array}$ & $25 \%$ & $\begin{array}{l}3 \mathrm{~S}, \\
2 \mathrm{~F}\end{array}$ & $10 \%$ & $\begin{array}{l}\text { IS, } \\
1 F\end{array}$ & & \\
\hline & Percentage of attitude value: & \multicolumn{4}{|c|}{$65 \%$} & \multicolumn{2}{|c|}{$25 \%$} & \multicolumn{4}{|c|}{$10 \%$} \\
\hline
\end{tabular}

Using the criterion explained earlier in the research method, the data show that generally students have positive habit (60\%), neutral readiness (65\%), neutral-to-negative accessibility (35\%-35\%), neutral comprehension (40\%), and positive evaluation (65\%) toward English listening. Further, in comparison from the perspective of students from EFL to ESL country, EFL students have better habit, better readiness, lesser accessibility, similar comprehension, and better evaluation than ESL students do. Thus, it is said that generally the students have neutralto-positive attitudes towards English listening, yet, EFL students' attitude shows better. 
From the table, it is seen that EFL students show higher interest in using songs, movies, and videos to improve their English and many of them do not really need subtitle although ESL students actually have more access to them. Correlating to later finding in reading and writing session, ESL students have better interest in English reading and writing, this can probably be the reason why ESL students' interest in movies, songs and videos does not really mean. However, they both have good attitudes in evaluation to English.

\section{Students' attitude towards speaking (question 6-10)}

To measure students' attitudes to speaking, the writer gave these 5 questions to be filled. These questions aimed to know students' attitudes to speaking skill focusing on five components indicating the attitudes, i.e., their fondness (Q6), confidence (Q7), meaningfulness focus (Q8), commitment (Q9), and evaluation (Q10) toward English speaking.

Table 2

Questionnaire Data Preview on Speaking Skill

\begin{tabular}{|c|c|c|c|c|c|c|c|c|c|c|c|}
\hline \multirow{3}{*}{$\frac{\mathrm{Na}}{6 .}$} & Statements & \multicolumn{2}{|c|}{ always } & \multicolumn{2}{|l|}{ often } & \multicolumn{2}{|c|}{ sometimes } & \multicolumn{2}{|c|}{ seldom } & \multicolumn{2}{|c|}{ never } \\
\hline & $\begin{array}{l}\text { English speaking is one of my } \\
\text { favorite classroomactivity }\end{array}$ & $25 \%$ & $5 \mathrm{~F}$ & $35 \%$ & $\begin{array}{l}5 \mathrm{~S}, \\
2 \mathrm{~F}\end{array}$ & $30 \%$ & $\begin{array}{l}4 S, \\
2 \mathrm{~F}\end{array}$ & $10 \%$ & $\begin{array}{l}\text { IS, } \\
\text { IF }\end{array}$ & & \\
\hline & Percentage of attitude value: & \multicolumn{4}{|c|}{$60 \%$} & \multicolumn{2}{|c|}{$30 \%$} & \multicolumn{4}{|c|}{$10 \%$} \\
\hline \multirow[t]{2}{*}{7.} & $\begin{array}{l}\text { Thaveno doubts and feel confident } \\
\text { to speak in English in class, in } \\
\text { seminar, and other formal situation }\end{array}$ & $20 \%$ & $\begin{array}{l}2 S, \\
2 F\end{array}$ & $45 \%$ & $\begin{array}{l}35, \\
6 \mathrm{~F}\end{array}$ & $15 \%$ & $\begin{array}{l}2 S, \\
1 F\end{array}$ & $15 \%$ & $\begin{array}{l}2 S, \\
1 F\end{array}$ & $5 \%$ & IS \\
\hline & Percentage of attitude value: & \multicolumn{4}{|c|}{$65 \%$} & \multicolumn{2}{|c|}{$15 \%$} & \multicolumn{4}{|c|}{$20 \%$} \\
\hline \multirow[t]{2}{*}{8.} & $\begin{array}{l}\text { Iam searching about 'ideas' rather } \\
\text { than 'words or grammars' while } \\
\text { speaking in English }\end{array}$ & $10 \%$ & 25 & $45 \%$ & $\begin{array}{l}4 S, \\
5 \mathrm{~F}\end{array}$ & $30 \%$ & $\begin{array}{l}2 \mathrm{~S}, \\
4 \mathrm{~F}\end{array}$ & $15 \%$ & $\begin{array}{l}2 S \\
1 F\end{array}$ & & \\
\hline & Percentage of attitude value: & \multicolumn{4}{|c|}{$55 \%$} & \multicolumn{2}{|c|}{$30 \%$} & \multicolumn{4}{|c|}{$15 \%$} \\
\hline \multirow[t]{2}{*}{9.} & $\begin{array}{l}\text { Ispeak English even to } \\
\text { acquaintances of samelocal } \\
\text { language }\end{array}$ & $5 \%$ & IS & $25 \%$ & $\begin{array}{l}2 S, \\
3 \mathrm{~F}\end{array}$ & $35 \%$ & $\begin{array}{l}3 \mathrm{~S} \\
4 \mathrm{~F}\end{array}$ & $20 \%$ & $\begin{array}{l}3 S, \\
\mathrm{IF}\end{array}$ & $15 \%$ & $\begin{array}{l}1 S, \\
2 \mathrm{~F}\end{array}$ \\
\hline & Percentage of attitude value: & \multicolumn{4}{|c|}{$30 \%$} & \multicolumn{2}{|c|}{$35 \%$} & \multicolumn{4}{|c|}{$35 \%$} \\
\hline \multirow[t]{2}{*}{10.} & $\begin{array}{l}\text { Iused to get good markin English } \\
\text { speaking activity }\end{array}$ & $20 \%$ & $\begin{array}{l}3 \mathrm{~S}, \\
\mathrm{lF}\end{array}$ & $40 \%$ & $\begin{array}{l}35, \\
5 \mathrm{~F}\end{array}$ & $30 \%$ & $\begin{array}{l}3 \mathrm{~S} \\
3 \mathrm{~F}\end{array}$ & $10 \%$ & 15 , & & \\
\hline & Percentage of attitude value: & \multicolumn{4}{|c|}{$60 \%$} & \multicolumn{2}{|c|}{$30 \%$} & \multicolumn{4}{|c|}{$10 \%$} \\
\hline
\end{tabular}


Using the criterion explained earlier in the research method, the data show that generally students have positive fondness $(60 \%)$, positive confidence $(65 \%)$, positive meaningfulness focus $(55 \%)$, neutral-tonegative commitment (40\%), and positive evaluation (65\%) toward English listening. Further, in comparison with the perspective of students from EFL to ESL country, EFL students have better fondness, better confidence, lesser meaningfulness focus, similar commitment, and similar evaluation as ESL students do. Thus, it is said that generally the students have positive attitude towards English speaking, with almost the same level of attitudes of both ESL and EFL students.

As to explain, EFL students have better fondness in speaking session (70\%) and have no doubts to speak in English (80\%) compared to ESL students; though in average they also show good attitudes in this. When speaking, half of them have confidence and think more ideas and half of them still think of 'what and how to say' and have problems of confidence. The majority of both ESL and EFL students do not prefer to use English to their acquaintances or relatives. However, many have good mark in speaking evaluation $(60 \%)$.

\section{Students' attitude towards reading (question 11-15)}

To measure students' attitudes to reading, the writer made these five questions to be filled. These questions were addressed to identify students' attitude in reading skill focusing on five indications, i.e., their habit (Q11), primary fondness (Q12), regular commitment (Q13), hard effort (Q14), and evaluation (Q15) toward English reading. 
Using the criterion explained earlier in the research method, the data show that generally students have positive habit (50\%), neutral primary fondness $(50 \%)$, positive regular commitment (60\%), negative/poor hard effort (40\%), and positive evaluation (45\%) towards English reading. Further, in comparison with the perspective of students from ESL to EFL country, ESL students have similar habit, better primary fondness, better regular commitment, better hard effort, and better evaluation than EFL students do. Thus, it is said that generally the students have positive attitudes towards English reading, but ESL students have better attitudes than EFL students do.

Table 3

Questionnaire Data Preview on Reading Skill

\begin{tabular}{|c|c|c|c|c|c|c|c|c|c|c|c|}
\hline No. & Statements & \multicolumn{2}{|c|}{ always } & \multicolumn{2}{|c|}{ often } & \multicolumn{2}{|c|}{ sometimes } & \multicolumn{2}{|c|}{ seldom } & \multicolumn{2}{|c|}{ never } \\
\hline \multirow[t]{2}{*}{11.} & $\begin{array}{l}\text { Iget used to read English book } \\
\text { sincechildhood }\end{array}$ & $15 \%$ & 35 & $35 \%$ & $\begin{array}{l}2 S, \\
5 \mathrm{~F}\end{array}$ & $25 \%$ & $\begin{array}{l}2 \mathrm{~S} \\
3 \mathrm{~F} \\
\end{array}$ & $15 \%$ & $\begin{array}{l}2 S, \\
1 F\end{array}$ & $10 \%$ & $\begin{array}{l}\mathrm{IS}, \\
\mathrm{IF}\end{array}$ \\
\hline & Percentage of attitude value: & \multicolumn{4}{|c|}{$50 \%$} & \multicolumn{2}{|c|}{$25 \%$} & \multicolumn{4}{|c|}{$25 \%$} \\
\hline \multirow[t]{2}{*}{12.} & $\begin{array}{l}\text { Ilike to read book in English better } \\
\text { than in any other languages }\end{array}$ & $30 \%$ & $\begin{array}{l}4 \mathrm{~S}, \\
2 \mathrm{~F}\end{array}$ & $15 \%$ & $\begin{array}{l}2 S, \\
1 F\end{array}$ & $50 \%$ & $\begin{array}{l}4 \mathrm{~S} \\
6 \mathrm{~F}\end{array}$ & $5 \%$ & IF & & \\
\hline & Percentage of attitude value: & \multicolumn{4}{|c|}{$45 \%$} & \multicolumn{2}{|c|}{$50 \%$} & \multicolumn{4}{|c|}{$5 \%$} \\
\hline \multirow[t]{2}{*}{13.} & $\begin{array}{l}\text { Ihaveregular habit to read English } \\
\text { books or newspapers or magazines }\end{array}$ & $35 \%$ & $\begin{array}{l}65, \\
1 F\end{array}$ & $25 \%$ & $\begin{array}{l}1, \\
4 \mathrm{~F}\end{array}$ & $30 \%$ & $\begin{array}{l}3 \mathrm{~S} \\
3 \mathrm{~F}\end{array}$ & $5 \%$ & $\mathrm{IF}$ & $5 \%$ & $\mathrm{IF}$ \\
\hline & Percentage of attitude value: & \multicolumn{4}{|c|}{$60 \%$} & \multicolumn{2}{|c|}{$30 \%$} & \multicolumn{4}{|c|}{$10 \%$} \\
\hline \multirow[t]{2}{*}{14.} & $\begin{array}{l}\text { Ihave experienced a very hard } \\
\text { effort to read advancelevel English } \\
\text { reading }\end{array}$ & $5 \%$ & IS & $20 \%$ & $\begin{array}{l}2 S, \\
2 F\end{array}$ & $35 \%$ & $\begin{array}{l}1 \mathrm{~S} \\
6 \mathrm{~F}\end{array}$ & $35 \%$ & $\begin{array}{l}5 \mathrm{~S}, \\
2 \mathrm{~F}\end{array}$ & $5 \%$ & 15 \\
\hline & Percentage of attitude value: & \multicolumn{4}{|c|}{$25 \%$} & \multicolumn{2}{|c|}{$35 \%$} & \multicolumn{4}{|c|}{$40 \%$} \\
\hline \multirow[t]{2}{*}{15.} & $\begin{array}{l}\text { Iused to get good markin English } \\
\text { reading activity }\end{array}$ & $20 \%$ & $\begin{array}{l}2 S, \\
2 F\end{array}$ & $25 \%$ & $\begin{array}{l}2 S, \\
3 \mathrm{~F}\end{array}$ & $30 \%$ & $\begin{array}{l}4 \mathrm{~S} \\
2 \mathrm{~F} \\
\end{array}$ & $10 \%$ & 25 & $15 \%$ & $3 \mathrm{~F}$ \\
\hline & Percentage of attitude value: & \multicolumn{4}{|c|}{$45 \%$} & \multicolumn{2}{|c|}{$30 \%$} & \multicolumn{4}{|c|}{$25 \%$} \\
\hline
\end{tabular}

To describe, ESL students have more fondness of reading English (60\%) than EFL students (30\%). It shows similarly to the fact that most of them have gotten used English reading as well as have regular reading 
habit. Academically, both ESL and EFL students have been evaluated good in English reading, though $30 \%$ of EFL students said 'never'. In addition, both ESL and ESL students have few efforts in challenging reading though $30 \%$ of Indians have good trials on that.

\section{Students' attitude towards writing (question 16-20)}

To detect students' attitude to writing, the writer used these following five questions. These questions were delivered to investigate students' attitude in writing skill concerning with five elements, i.e., their habit (Q16), regular commitment (Q17), challenged passion (Q18), professional effort (Q19), and evaluation (Q15) toward English writing.

Table 4

Questionnaire Data Preview on Writing Skill

\begin{tabular}{|c|c|c|c|c|c|c|c|c|c|c|c|}
\hline \multirow{3}{*}{\begin{tabular}{|l} 
No \\
16. \\
\end{tabular}} & \multirow{2}{*}{$\begin{array}{l}\text { Statements } \\
\text { Iget used to write in English since } \\
\text { childhood or young }\end{array}$} & \multicolumn{2}{|c|}{ always } & \multicolumn{2}{|c|}{ often } & \multicolumn{2}{|c|}{ sometimes } & \multicolumn{2}{|c|}{ seldom } & \multicolumn{2}{|c|}{ never } \\
\hline & & $25 \%$ & $\begin{array}{l}4 S, \\
1 F\end{array}$ & $20 \%$ & $\begin{array}{l}3 S, \\
\mathrm{IF}\end{array}$ & $35 \%$ & $\begin{array}{l}2 S \\
5 \mathrm{~F}\end{array}$ & $5 \%$ & $\mathrm{IF}$ & $15 \%$ & $\begin{array}{l}15, \\
2 S\end{array}$ \\
\hline & Percentage of attitude value: & \multicolumn{4}{|c|}{$45 \%$} & \multicolumn{2}{|c|}{$35 \%$} & \multicolumn{4}{|c|}{$20 \%$} \\
\hline \multirow[t]{2}{*}{17.} & $\begin{array}{l}\text { Ihavemy own regular agenda to } \\
\text { write in English (diary, poem, } \\
\text { article, book,etc) }\end{array}$ & $5 \%$ & 15 & $10 \%$ & $\begin{array}{l}\text { IS, } \\
\text { IF }\end{array}$ & $25 \%$ & $\begin{array}{l}3 \mathrm{~S} \\
2 \mathrm{~F}\end{array}$ & $20 \%$ & $\begin{array}{l}2 S, \\
2 F\end{array}$ & $40 \%$ & $\begin{array}{l}3 \mathrm{~S}, \\
5 \mathrm{~F}\end{array}$ \\
\hline & Percentage of attitude value: & \multicolumn{4}{|c|}{$15 \%$} & \multicolumn{2}{|c|}{$25 \%$} & \multicolumn{4}{|c|}{$60 \%$} \\
\hline \multirow[t]{2}{*}{18.} & $\begin{array}{l}\text { Ifeel challenged rather than afraid } \\
\text { or bad when writing in English }\end{array}$ & $15 \%$ & $\begin{array}{l}15, \\
2 \mathrm{~F}\end{array}$ & $25 \%$ & $\begin{array}{l}2 S, \\
3 F\end{array}$ & $15 \%$ & $\begin{array}{l}1 S \\
2 \mathrm{~F}\end{array}$ & $15 \%$ & $3 S$ & $30 \%$ & $\begin{array}{l}3 \mathrm{~S}, \\
3 \mathrm{~F}\end{array}$ \\
\hline & Percentage of attitude value: & \multicolumn{4}{|c|}{$40 \%$} & \multicolumn{2}{|c|}{$15 \%$} & \multicolumn{4}{|c|}{$45 \%$} \\
\hline \multirow[t]{2}{*}{19.} & $\begin{array}{l}\text { Ihave ever published English } \\
\text { writing }(\mathrm{s}) \text { (poem, article, anecdote } \\
\text { etc) even once }\end{array}$ & & & $5 \%$ & 15 & $15 \%$ & $3 S$ & $20 \%$ & $\begin{array}{l}2 S, \\
2 F\end{array}$ & $60 \%$ & $\begin{array}{l}4 S, \\
8 \mathrm{~F}\end{array}$ \\
\hline & Percentage of attitude value: & \multicolumn{4}{|c|}{$5 \%$} & \multicolumn{2}{|c|}{$15 \%$} & \multicolumn{4}{|c|}{$80 \%$} \\
\hline \multirow[t]{2}{*}{20.} & $\begin{array}{l}\text { Iused to get good markin English } \\
\text { writing a ctivity }\end{array}$ & $10 \%$ & $\begin{array}{l}\text { IS, } \\
\text { IF }\end{array}$ & $50 \%$ & $\begin{array}{l}65, \\
4 \mathrm{~F}\end{array}$ & $25 \%$ & $\begin{array}{l}2 S \\
3 \mathrm{~F}\end{array}$ & $10 \%$ & $\begin{array}{l}1 S, \\
\text { IF }\end{array}$ & $5 \%$ & IF \\
\hline & Percentage of attitude value: & \multicolumn{4}{|c|}{$60 \%$} & \multicolumn{2}{|c|}{$25 \%$} & \multicolumn{4}{|c|}{$15 \%$} \\
\hline
\end{tabular}


Using the criterion explained earlier in the research method, the data show that generally students have positive habit (45\%), negative regular commitment (60\%), negative challenged passion (60\%), negative professional effort (40\%), and positive evaluation (60\%) towards English reading. Further, in comparison with the perspective of students from ESL to EFL country, ESL students have better habit, better regular commitment, lesser challenged passion, better professional effort, and better evaluation than EFL students do. Thus, it is said that generally the students have negative attitudes towards English writing, and ESL students dominantly have better attitudes than EFL students do.

To add, the majority of ESL students, they are Indians, have gotten used to write in English (70\%) and even 60\% of them experience publishing their article, while only $20 \%$ of EFL students get used to write and similarly only $20 \%$ have experience in publishing their English writing. This is probably because, in India, English learning attempts more on reading and writing and schools give more practice and task on them. However, both ESL students and EFL students have good evaluations in English. Other same things are few ESL and EFL have regular habit on writing and feel challenged when writing English.

\section{Conclusion}

In conclusion, this study finally found that generally English students in EFL University have neutral-to-positive attitude towards English listening, positive attitude towards English speaking, positive attitude towards English reading, and negative attitude towards English writing. Further, students from ESL country have better attitude in 
Reading and Writing, and vice versa, students from EFL country have better attitude in Listening and Speaking. This finding then recommends that English learners need to create good habit and attitude towards English to make their English learning meaningful, effective and applicable, since the heart of a language is not to be learned as a science, but rather to be used in daily life, verbally and nonverbally.

\section{References}

Cohen, L., Manion, L., and Morrison, K. 2000. Research Methods in Education (Fifth Edition).London and New York: Routledge Falmer.

Karahan, F. 2007. Language Attitudes of Turkish Students towards the English Languageand Its Use in Turkish Context. Journal of Arts and Sciences Say, 7 May, 73-87.

Rejecky, D. W. 1982. Attitude Themes and Advances. Sunderland Snouer Associates Inc.

Smit, V. 1996.ANew English for a New South Africa: Language Attitudes Planning and Education. Vienna: Braumuller.

Sugiyono. 2008. Metode Penelitian Kuantitatif, Kualitatif dan $R \& D$. Bandung: Alfabeta.

Wenden, A. 1991. Learner Strategies for Learner Autonomy. London: Prentice Hall. 